\title{
Investigation of sperm cytotoxicity as an indicator of ability of antisera to detect male-specific antigen on preimplantation mouse embryos
}

\author{
J. A. Piedrahita and G. B. Anderson \\ Department of Animal Science, University of California, Davis, California 95616, U.S.A.
}

\begin{abstract}
Summary. H-Y antisera were produced in $\mathrm{C} 57 \mathrm{BL} / 6$ female mice by repeated intraperitoneal injections of syngeneic male spleen cells. Epididymal spermatozoa were incubated in the presence of $\mathrm{H}-\mathrm{Y}$ antisera and guinea-pig serum as a complement source. Levels of ATP remaining after treatment were used to calculate the amount of specific killing. Sera of different cytotoxic titres were used in an indirect immunofluorescent assay with a fluorescein isothiocyanate-conjugated IgG fraction of goat anti-mouse IgG (Fc fragment specific) as second antibody. Embryos were classified as fluorescent or nonfluorescent, transferred to pseudopregnant recipients, and allowed to develop to term. Of 12 sera tested for sperm cytotoxicity, 5 were different from a nonimmunized control serum $(P<0.05)$. Percentage specific killing in each of these sera was $7 \cdot 8 \pm 4 \cdot 2,11 \cdot 7 \pm 3 \cdot 0,26 \cdot 0 \pm 2 \cdot 2,27 \cdot 7 \pm 3 \cdot 7$ and $39 \cdot 2 \pm 4 \cdot 8$, respectively (mean \pm s.e.m. with three replicates). The 5 sera and an additional one $(4.9 \pm 1.3 \%$ specific killing) were used in the embryo sexing experiment. The accuracy with which these sera correctly identified sex of preimplantation embryos was 60,46 , $74,73,74$ and $48 \%$, respectively. Correlation coefficients were $0.86(P<0.05)$ for specific sperm cytotoxicity and percentage of nonfluorescent embryos that were female and 0.78 (n.s.) for specific sperm cytotoxicity and percentage of fluorescent embryos that were male. Therefore, although the sperm cytotoxicity test is useful for screening antisera for the study of $\mathrm{H}-\mathrm{Y}$ antigen expression on preimplantation embryos, nonfluorescent embryos are more accurately classified as females than are fluorescent embryos as male.
\end{abstract}

\section{Introduction}

The H-Y antigen was first detected when it was observed that female mice rejected skin grafts from male syngeneic mice (Eichwald \& Silmser, 1955). Since then H-Y antigen has been detected in all species tested and has been found associated with the heterogametic sex (Wachtel, Koo \& Boyce, 1975). However, there has been some controversy as to whether there are two different malespecific antigens, one detected by transplant rejection ( $\mathrm{H}-\mathrm{Y}$ antigen) and one detected by serological methods (serologically detectable male antigen or SDM) (Simpson, McLaren \& Chandler, 1982): the results of Koo \& Varano (1981) and Koo, Reidy \& Nagamine (1983) contradict those of Simpson et al. (1982). Wachtel et al. (1984) reported that the H-Y transplantation antigen and SDM antigen were either identical or highly cross-reactive. In this paper the term $\mathrm{H}-\mathrm{Y}$ antigen will be used with the understanding that there is still controversy as to whether SDM and H-Y antigen are the same.

Because of the exclusive presence of $\mathrm{H}-\mathrm{Y}$ antigen in the mammalian male (Wachtel et al., 1975) and its presence early in embryonic development (Krco \& Goldberg, 1976), detection of the H-Y antigen on preimplantation embryos has been used as a tool for predicting the phenotypic sex of the offspring (White, Lindner, Anderson \& BonDurant, 1982, 1983; Wachtel, 1984; White, Bradbury, 
Anderson \& BonDurant, 1984). Selection of antiserum to be used for H-Y antigen detection (H-Y antiserum) is based currently on results obtained from a complement-dependent cytotoxicity test using spermatozoa as target cells (Goldberg, Boyce, Bennett, Scheid \& Carswell, 1971). It is not known whether this technique provides an acceptable indication of the ability of a particular antiserum to detect embryonic $\mathrm{H}-\mathrm{Y}$ antigen. These experiments were undertaken to determine the degree of association between the results obtained in the sperm cytotoxicity test and the ability of individual antisera to detect $\mathrm{H}-\mathrm{Y}$ antigen on preimplantation mouse embryos.

\section{Materials and Methods}

Antiserum preparation. H-Y antisera were obtained by immunizing C57BL/6 female mice with syngeneic male spleen cells. Spleen cell suspensions were prepared by gentle dissociation of spleens in phosphate-buffered saline (PBS) (Dulbecco \& Vogt, 1954). Connective tissue and large cell aggregates were removed by centrifugation at $250 \mathrm{~g}$ for $15-20 \mathrm{sec}$. The spleen cell suspension contained in the supernatant was washed twice, each wash being followed by centrifugation at $250 \mathrm{~g}$ for $10 \mathrm{~min}$. After the second wash and centrifugation the pellet was resuspended in PBS and cell numbers determined with a haemocytometer.

Three different immunization schedules were used. Ten animals (Mice 1-10) received intraperitoneal injections of $80 \sim 100 \times 10^{6}$ spleen cells three times a week for 3 weeks followed by booster injections of $80-100 \times 10^{6}$ spleen cells every 2 weeks. One mouse (No. $1 \mathrm{~N}$ ) received 80-100 $\times 10^{6}$ once a week for 3 weeks followed by booster injections of $80-100 \times 10^{6}$ every 2 weeks, and replaced Mouse 1, which died during immunization. In the third immunization schedule, antisera were obtained by a modification of the method of White et al. (1982). The modification consisted of injection of Mice $1 \mathrm{~K}$ and $2 \mathrm{~K}$ with $40-50 \times 10^{6}$ male spleen cells three times a week for 3 weeks followed by injections of $40-50 \times 10^{6}$ spleen cells every 2 weeks.

Antisera from Mice 2-10 and Mouse $1 \mathrm{~N}$ were obtained from $300-400 \mu$ blood collected by tail bleeding 5-7 days after the most recent booster injection, starting 8 weeks after the first injection. Serum was collected from each animal a maximum of once a month. Antisera from Mice $1 \mathrm{~K}$ and $2 \mathrm{~K}$ were obtained by collection of blood from the retro-orbital sinus of the anaesthetized mouse. Antisera were heat-treated at $56^{\circ} \mathrm{C}$ for $30 \mathrm{~min}$, absorbed with spleen cells from males or females and stored at $-32^{\circ} \mathrm{C}$ until use, but never for longer than 1 week.

Antiserum absorptions. The antisera $(100 \mu 1)$ were absorbed twice with $20-40 \times 10^{6}$ spleen cells obtained from male or female C57BL/6 mice. Absorptions were carried out at $4^{\circ} \mathrm{C}$ for $30 \mathrm{~min}$.

Sperm cytotoxicity test. Epididymal spermatozoa were obtained from C57BL/6 mice by the method of Tung, Gore-Langton \& Fritz (1982). To $5 \times 10^{6}$ spermatozoa were added $50 \mu 1$ heattreated $\mathrm{H}-\mathrm{Y}$ antiserum, followed by $50 \mu \mathrm{l}$ of a $1: 3$ dilution of normal guinea-pig serum (Gibco, Grand Island, NY), which had been previously screened for low toxicity to mouse spermatozoa, as a complement source. The sperm suspension was incubated at $37^{\circ} \mathrm{C}$ for $45 \mathrm{~min}$, and then $500 \mu \mathrm{l}$ boiling water were added to stop the cytotoxic reaction. Samples were placed in a $100^{\circ} \mathrm{C}$ water bath for 15 min to extract ATP (adenosine triphosphate) from the spermatozoa, diluted with distilled water to a final volume of $5 \mathrm{ml}$ and frozen at $-32^{\circ} \mathrm{C}$ until needed. Samples were analysed in triplicate and coded for identification before the ATP assay.

$A T P$ assay. The ATP assay is based on the ability of the enzyme luciferin-luciferase to produce an amount of light proportional to the concentration of ATP in the test solution. ATP standards containing $10^{-7} \mathrm{M}$ to $10^{-10} \mathrm{M}$ ATP in distilled water and the luciferin-luciferase reagent $(50 \mathrm{mg} / \mathrm{ml})$ (Sigma, St Louis, MO) were prepared on the day of the assay and kept at $4^{\circ} \mathrm{C}$. Standard curves were prepared at the beginning and end of each assay to correct for potential changes in enzyme activity with time. ATP measurements were performed on one sample at a time. To $40 \mu$ reconstituted luciferin-luciferase reagent, $10 \mu \mathrm{l}$ of test sample were injected and the light produced during a 30 - 
sec interval determined with a luminometer (United Technologies, Packard model 6100 Picolite). With these procedures the minimum detectable level of ATP was $10^{-16} \mathrm{M}$. From the standard curve it was calculated that 5 to $10 \%$ differences in production of light could be detected. Percentage lysed cells was calculated according to the method of Tung et al. (1982).

Detection of $\mathrm{H}-\mathrm{Y}$ on mouse embryos. All embryo manipulations were carried out in PBS supplemented with $0.036 \mathrm{mg}$ sodium pyruvate $/ \mathrm{ml}$ (Sigma) $2.8 \mathrm{mg}$ sodium lactate $/ \mathrm{ml}$ (Sigma), 1.0 $\mathrm{mg}$ glucose $/ \mathrm{ml}$ (Sigma), $0.01 \mathrm{mg}$ antibiotic-mycostatic solution $/ \mathrm{ml}$ (Gibco), and $2.5 \mathrm{mg} \mathrm{BSA} / \mathrm{ml}$ (bovine serum albumin; Sigma). H-Y antisera absorbed twice with female spleen cells, and fluorescein isothiocyanate-(FITC-)conjugated IgG fraction of goat anti-mouse IgG (Fc fragment specific) (Cappel Laboratories, Cochranville, PA) were diluted in the same medium except that no BSA was added. Female mice of different strains (06, JU, C57BL/6) (06, Bradford, 1968; JU, Eklund \& Bradford, 1976) were mated and embryos were flushed from the uteri on the morning of Day 3 (Day 0 designated as day of oestrus). Embryos were evaluated under a dissecting microscope and those at the appropriate stages of development (early to expanded blastocyst) were washed three times in PBS and placed in $30 \mu 1$ drops containing antiserum diluted $1: 1$ in modified PBS. Embryos were incubated for $30 \mathrm{~min}$ at $37^{\circ} \mathrm{C}$, gently washed three times in modified PBS to remove unbound antibodies and placed in $30 \mu \mathrm{l}$ drops containing a $1: 9$ dilution of FITC-labelled goat antimouse IgG for $30 \mathrm{~min}$ at $37^{\circ} \mathrm{C}$. Embryos were washed three times in modified PBS to remove unbound antibodies and thus reduce background fluorescence, placed in individual wells in a microtitre plate (Falcon, Oxnard, CA) and evaluated under an inverted light microscope equipped for fluorescent excitation. All incubations were carried out in an humidified atmosphere of $5 \% \mathrm{CO}_{2}$ and air.

Embryos were classified as $\mathrm{H}-\mathrm{Y}$ positive if areas of granular or intense, localized fluorescence were observed. Embryos were classified as $\mathrm{H}-\mathrm{Y}$ negative if only diffuse (non-specific) fluorescence was detected. An effort was made to classify approximately half of the embryos as fluorescent and half nonfluorescent. The relative difference between $\mathrm{H}-\mathrm{Y}$ positive and $\mathrm{H}-\mathrm{Y}$ negative embryos varied according to the antiserum being tested and there was considerable subjectivity with some antisera, presumably those of low anti-H-Y titres. Embryos classified as $\mathrm{H}-\mathrm{Y}$ positive or $\mathrm{H}-\mathrm{Y}$ negative were transferred separately to the uteri of pseudopregnant recipients. Control transfers consisted of embryos that were transferred immediately after collection, transferred after incubation in antiserum, or transferred after incubation in FITC-labelled antibody alone. Sex of the resulting young was determined at birth by examination of the external genitalia.

Transfer of embryos. Pseudopregnancy was induced in recipients by mating to vasectomized males. On Day 2 of pseudopregnancy (oestrus = Day 0 ) general anaesthesia was induced by intraperitoneal injection of $0.1 \mathrm{ml}$ Avertin $(1.25 \mathrm{~g} \mathrm{2,2,2-dibromoethanol} / 100 \mathrm{ml}$ and $3.13 \mathrm{ml} \mathrm{2-}$ methyl-2-butanol $/ 100 \mathrm{ml}$ in distilled water) $/ 5 \mathrm{~g}$ body weight. The ovary and adjacent uterine horn were exposed via a paracostal incision and a 27 -gauge needle used to reach the uterine lumen at the tip of the horn. The tip of a small glass micropipette containing the embryos was introduced through the puncture site. The embryos were gently released into the lumen and the uterus and ovary were returned to the body cavity. The incision was closed with surgical clips and the procedure was repeated on the other side. Usually 4-6 embryos were transferred to each uterine horn. All transfers of embryos were carried out by one individual.

Statistical analysis. Individual differences in percentage specific killing at a $1 / 8 \mathrm{H}-\mathrm{Y}$ antiserum dilution were analysed by F test. Mean separation was accomplished by Duncan's multiple range test (Little \& Hills, 1978). The Wilcoxon two-sample rank sum test was used to test for differences in percentage killing between male- and female-absorbed antisera at different dilutions (Choi, 1978). The experimental design for embryonic $\mathrm{H}-\mathrm{Y}$ detection consisted of a completely randomized design with unequal replications. Each replicate consisted of results obtained from antiserum collected on a particular date. Sera were collected from mice on three separate occasions except for Mice $1 \mathrm{~K}$ and $2 \mathrm{~K}$, from which sera were collected only twice. Results were expressed as percentages 
and analysed for homogeneity of variance by Bartletts test (Little \& Hills, 1978). Treatment effects on pregnancy rates and embryo survival rates were analysed by one-way analysis of variance and Duncan's multiple range test. Treatment differences in proportion of fluorescent and nonfluorescent embryos and proportion of male offspring were tested by $\chi^{2}$ analysis (Choi, 1978). Correlation between sperm cytotoxicity $(X-Y)$ and the proportions of accurately classified male and female embryos and overall accuracy $(Z)$ were calculated by the formula $\operatorname{CORR}(Z, X-Y)=$ $\operatorname{COV}(\mathrm{Z}, \mathrm{X}-\mathrm{Y}) / \operatorname{VAR}(\mathrm{Z})^{*} \operatorname{VAR}(\mathrm{X}-\mathrm{Y})$.

\section{Results}

Of the 10 mice immunized with $80-100 \times 10^{6}$ male spleen cells three times a week for 3 weeks (Table 1), only two gave antiserum titres that were different from the control $(P<0.05)$. Although different from the control, their H-Y-specific titres were lower than those found in mice injected with fewer spleen cells. Sera from Mouse $1 \mathrm{~N}$, which was injected once a week for 3 weeks with 80 $100 \times 10^{6}$ male spleen cells, had several times the cytotoxic activity as did those of Mice 3 and 10 . Sera from Mice $1 \mathrm{~K}$ and $2 \mathrm{~K}$, which received 40-50 $\times 10^{6}$ male spleen cells three times a week for 3 weeks, had specific anti-H-Y activity comparable to that of Mouse $1 \mathrm{~N}$. When additional experiments were performed on $\mathrm{H}-\mathrm{Y}$ antisera from Mice 3,10, and $1 \mathrm{~N}$ (Text-fig. 1), the maleabsorbed sera differed from the female-absorbed sera in Mouse $1 \mathrm{~N}(P<0.05)$, but not in Mice 3 and 10 .

Six of the mice (Mice 3, 6,10,1N, $1 \mathrm{~K}$ and $2 \mathrm{~K}$ ) were selected as sources of $\mathrm{H}$-Y antisera for detection of embryonic $\mathrm{H}-\mathrm{Y}$ antigen. Two different populations of embryos, fluorescent and nonfluorescent, were obtained with each of the H-Y antisera tested. The trend, however, was for $\mathrm{H}-\mathrm{Y}$ antisera of low sperm cytotoxic activity to give a lower percentage of fluorescent embryos. The number of fluorescent embryos versus the total number tested for antisera from Mice 3, 6, 10, 1N, $1 \mathrm{~K}$ and $2 \mathrm{~K}$ were $123 / 267(46 \%), 105 / 228(46 \%), 125 / 272(46 \%), 139 / 251(55 \%), 143 / 259(55 \%)$ and $146 / 256(57 \%)$, respectively. Results from Table 2 show that with $\mathrm{H}-\mathrm{Y}$ antisera of low titres, as determined by the sperm cytotoxicity test, sex of embryos was not accurately identified, but with $\mathrm{H}^{-}$ $\mathrm{Y}$ antisera of high titres the sex of the embryos in 3 out of 6 groups was identified correctly $(P<$

Table 1. Cytotoxic activity of $\mathrm{H}-\mathrm{Y}$ antisera as determined by ATP assay on treated spermatozoa

\begin{tabular}{|c|c|c|c|}
\hline \multirow[b]{2}{*}{$\begin{array}{l}\text { Serum } \\
\text { source }\end{array}$} & \multicolumn{3}{|c|}{ Percentage dead spermatozoa (mean \pm s.e.m.) } \\
\hline & $\begin{array}{l}\text { Female } \\
\text { absorbed }\end{array}$ & $\begin{array}{c}\text { Male } \\
\text { absorbed }\end{array}$ & $\begin{array}{l}\text { Specific } \\
\left(\emptyset-\sigma^{\top}\right)\end{array}$ \\
\hline Controlt & $21.5 \pm 1.4$ & $21.9 \pm 1.5$ & $-0.4 \pm 2.9$ \\
\hline Mouse 2 & $22.0 \pm 1.6$ & $20.9 \pm 1.4$ & $1 \cdot 1 \pm 3 \cdot 0^{3 b}$ \\
\hline Mouse 3 & $32.2 \pm 1.7$ & $24.4 \pm 2.5$ & $7 \cdot 8 \pm 4 \cdot 2^{\mathrm{bc}}$ \\
\hline Mouse 4 & $26.0 \pm 0.6$ & $21.7 \pm 1.0$ & $3.6 \pm 1.5^{\mathrm{ab}}$ \\
\hline Mouse 5 & $22.7 \pm 2.0$ & $22.4 \pm 1.4$ & $0.3 \pm 3.4^{\mathrm{ab}}$ \\
\hline Mouse 6 & $24.7 \pm 1.0$ & $19.8 \pm 0.4$ & $4.9 \pm 1 \cdot 3^{a+x}$ \\
\hline Mouse 7 & $26.5 \pm 1.6$ & $20.7 \pm 1.0$ & $5 \cdot 8 \pm 2 \cdot 5^{\mathrm{jbc}}$ \\
\hline Mouse 8 & $22.9 \pm 1.3$ & $21.0 \pm 1.6$ & $1.9 \pm 2.9^{a b}$ \\
\hline Mouse 9 & $25.5 \pm 0.4$ & $22.3 \pm 0.8$ & $3 \cdot 2 \pm 1 \cdot 2^{\mathrm{ab}}$ \\
\hline Mouse 10 & $34.7 \pm 2.6$ & $23.0 \pm 0.7$ & $11 \cdot 7 \pm 3 \cdot 0^{\mathrm{c}}$ \\
\hline Mouse IN & $48 \cdot 6 \pm 2 \cdot 0$ & $20.9 \pm 1.8$ & $27 \cdot 7 \pm 3 \cdot 7^{\mathrm{d}}$ \\
\hline Mouse IK & $45.6 \pm 1.9$ & $19.6 \pm 0.5$ & $26 \cdot 0 \pm 2 \cdot 2^{d}$ \\
\hline Mouse $2 \mathrm{~K}$ & $66.6 \pm 4.4$ & $27 \cdot 4 \pm 1 \cdot 0$ & $39.2 \pm 5.4^{e}$ \\
\hline
\end{tabular}

$\dagger$ Nonimmunized mouse.

Means with different superscript letters differ significantly $(P<0.05)$. 


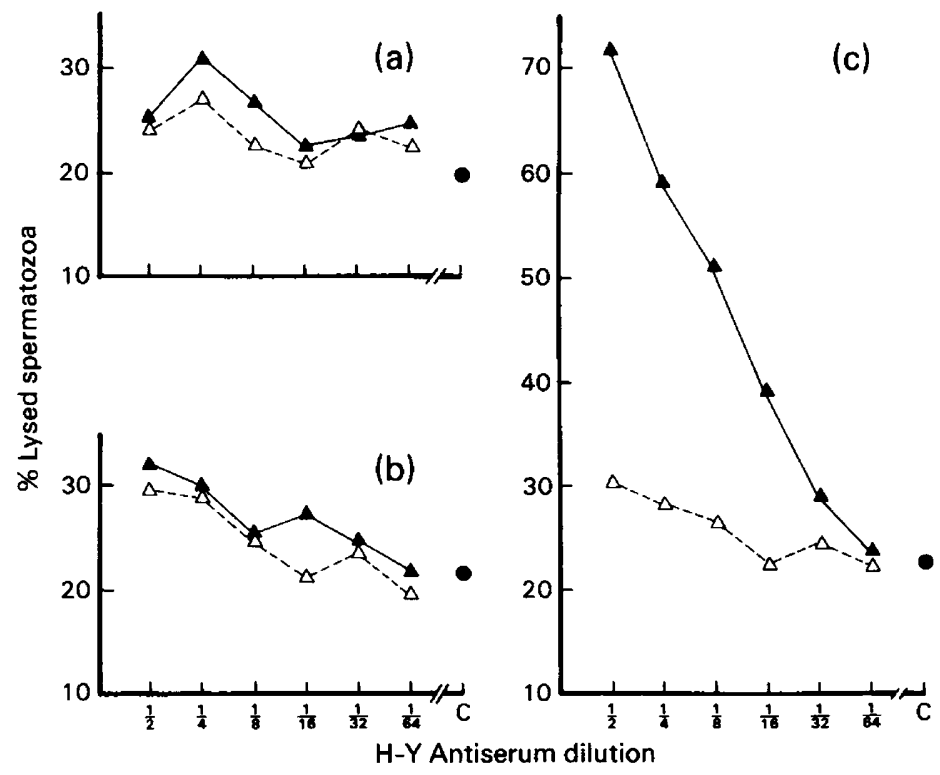

Text-fig. 1. Sperm cytotoxic activity of H-Y antiserum from (a) Mouse 3, (b) Mouse 10 and (c) Mouse IN as measured by ATP assay. Values are shown for antiserum absorbed with spleen cells from female C57BL/6 mice $(\Delta)$ or from male C57BL/6 mice $(\triangle)$. Cytotoxicity with guinea-pig serum alone $(O)$ is also shown.

Table 2. Sex distribution of young at birth after an indirect immunofluorescent assay for $\mathrm{H}-\mathrm{Y}$ antigen detection

\begin{tabular}{llrr}
\hline \multirow{2}{*}{$\begin{array}{l}\text { Serum } \\
\text { source }\end{array}$} & $\begin{array}{c}\text { Embryo } \\
\text { classification }\end{array}$ & \multicolumn{2}{c}{ No. of young born $(\%)$} \\
\cline { 3 - 4 } Control & - & $81(49 \cdot 1)$ & $84(50 \cdot 9)$ \\
Mouse 3 & Male & Female \\
& Noorescent & $14(63 \cdot 6)$ & $8(36 \cdot 4)$ \\
Mouse 6 & Fluorescent & $14(43 \cdot 8)$ & $18(56 \cdot 2)$ \\
& Nonfluorescent & $19(50 \cdot 0)$ & $9(50 \cdot 0)$ \\
Mouse 10 & Fluorescent & $13(48 \cdot 1)$ & $16(45 \cdot 7)$ \\
& Nonfluorescent & $15(55 \cdot 6)$ & $12(44 \cdot 9)$ \\
Mouse 1N & Fluorescent & $29(65 \cdot 9)$ & $15(34 \cdot 1)$ \\
& Nonfluorescent & $5(20 \cdot 8)$ & $19(79 \cdot 2)^{*}$ \\
Mouse 1K & Fluorescent & $20(64 \cdot 5)$ & $11(35 \cdot 5)$ \\
& Nonfluorescent & $5(17 \cdot 2)$ & $24(82 \cdot 8)^{*}$ \\
Mouse 2K & Fluorescent & $32(71 \cdot 1)$ & $13(28.9)^{*}$ \\
& Nonfluorescent & $4(22 \cdot 2)$ & $14(77 \cdot 8)$ \\
\hline
\end{tabular}

* Values are significantly different from $1: 1$ ratio $(P<0.05)$.

$0.05)$. The percentage of accurately classified embryos treated with antisera from Mice $1 \mathrm{~N}, 1 \mathrm{~K}$ and $2 \mathrm{~K}$ tended to be higher in the nonfluorescent group than in the fluorescent group (Table 3). Correlation coefficients between the cytotoxic activity of $\mathrm{H}-\mathrm{Y}$ antiserum and the percentage of fluorescent embryos that were male, nonfluorescent embryos that were female and combined or 
Table 3. Percentage of embryos correctly classified as to sex by antisera of different anti $\mathrm{H}-\mathrm{Y}$ titres

\begin{tabular}{|c|c|c|c|c|}
\hline \multirow{2}{*}{$\begin{array}{l}\text { Serum } \\
\text { source }\end{array}$} & \multirow{2}{*}{$\begin{array}{c}\text { Cytotoxic } \\
\text { activity } \\
\text { (mean } \pm \text { s.e.m.) }\end{array}$} & \multicolumn{3}{|c|}{ Embryos correctly classified by sex $(\%)$} \\
\hline & & Fluorescent & Nonfluorescent & Combined \\
\hline Mouse 3 & $7.8 \pm 4.2$ & 63.6 & $56 \cdot 2$ & 59.9 \\
\hline Mouse 6 & $4.9 \pm 1.3$ & $50 \cdot 0$ & $45 \cdot 7$ & $47 \cdot 9$ \\
\hline Mouse 10 & $11.7 \pm 3.0$ & $48 \cdot 1$ & $44 \cdot 4$ & $46 \cdot 3$ \\
\hline Mouse IN & $27.7 \pm 3.7$ & $65 \cdot 9$ & $79 \cdot 2$ & $72 \cdot 6$ \\
\hline Mouse IK & $26 \cdot 0 \pm 2 \cdot 2$ & $64 \cdot 5$ & 82.8 & $73 \cdot 7$ \\
\hline Mouse $2 \mathrm{~K}$ & $39 \cdot 2 \pm 5 \cdot 4$ & $71 \cdot 1$ & 77.8 & $74 \cdot 5$ \\
\hline
\end{tabular}

Table 4. Effect of the indirect immunofluorescent assay on embryonic survival

\begin{tabular}{|c|c|c|c|c|}
\hline \multirow[b]{2}{*}{$\begin{array}{l}\text { Serum } \\
\text { source }\end{array}$} & \multirow{2}{*}{$\begin{array}{c}\text { Presumptive } \\
\text { H-Y } \\
\text { status }\end{array}$} & \multirow{2}{*}{$\begin{array}{c}\text { No. of } \\
\text { pregnant } \\
\text { recipients }(\%)\end{array}$} & \multicolumn{2}{|c|}{$\begin{array}{c}\text { No. of embryos surviving } \\
\text { to term }(\%)\end{array}$} \\
\hline & & & $\begin{array}{l}\text { All } \\
\text { recipients }\end{array}$ & $\begin{array}{l}\text { Pregnant } \\
\text { recipients }\end{array}$ \\
\hline Mouse 3 & $\begin{array}{l}\text { Positive } \\
\text { Negative }\end{array}$ & $\begin{array}{l}5(44) \\
8(53)\end{array}$ & $\begin{array}{l}22(17) \\
32(22)\end{array}$ & $\begin{array}{l}22(32)^{c} \\
32(37)^{c}\end{array}$ \\
\hline Mouse 6 & $\begin{array}{l}\text { Positive } \\
\text { Negative }\end{array}$ & $\begin{array}{l}5(44) \\
6(58)\end{array}$ & $\begin{array}{l}18(17) \\
35(28)\end{array}$ & $\begin{array}{l}18(38)^{\mathrm{c}} \\
35(45)^{\mathrm{abc}}\end{array}$ \\
\hline Mouse 10 & $\begin{array}{l}\text { Positive } \\
\text { Negative }\end{array}$ & $\begin{array}{l}5(42) \\
4(33)\end{array}$ & $\begin{array}{l}27(22) \\
27(19)\end{array}$ & $\begin{array}{l}27(57)^{\mathrm{a}} \\
27(55)^{\mathrm{ab}}\end{array}$ \\
\hline Mouse 1N & $\begin{array}{l}\text { Positive } \\
\text { Negative }\end{array}$ & $\begin{array}{l}7(58) \\
5(42)\end{array}$ & $\begin{array}{l}44(32) \\
24(22)\end{array}$ & $\begin{array}{l}44(47)^{\mathrm{abc}} \\
24(43)^{\mathrm{abc}}\end{array}$ \\
\hline Mouse $1 \mathrm{~K}$ & $\begin{array}{l}\text { Positive } \\
\text { Negative }\end{array}$ & $\begin{array}{l}6(50) \\
8(67)\end{array}$ & $\begin{array}{l}31(21) \\
29(25)\end{array}$ & $\begin{array}{l}31(38)^{\mathrm{bc}} \\
29(33)^{\mathrm{c}}\end{array}$ \\
\hline Mouse $2 \mathrm{~K}$ & $\begin{array}{l}\text { Positive } \\
\text { Negative }\end{array}$ & $\begin{array}{l}8(56) \\
6(49)\end{array}$ & $\begin{array}{l}45(30) \\
18(16)\end{array}$ & $\begin{array}{l}45(43)^{\mathrm{abc}} \\
18(30)^{\mathrm{c}}\end{array}$ \\
\hline $\begin{array}{l}\text { Control } \\
\text { transfers* }\end{array}$ & $\begin{array}{l}\text { (1) Direct } \\
\text { (2) FITC } \\
\text { (3) Antisera }\end{array}$ & $\begin{array}{l}14(70) \\
11(61) \\
14(64)\end{array}$ & $\begin{array}{l}60(23) \\
47(21) \\
58(22)\end{array}$ & $\begin{array}{l}60(33)^{\mathrm{c}} \\
47(34)^{\mathrm{c}} \\
58(38)^{\mathrm{c}}\end{array}$ \\
\hline
\end{tabular}

Values with different superscript letters differ significantly $(P<0 \cdot 05)$.

* (1) Embryos transferred without any treatment; (2) embryos transferred after incubation in FITC only; (3) embryos transferred after incubation in antiserum only.

overall accuracy were $0.78,0.86$ and 0.86 , respectively. The correlations were significant $(P<0.05)$ for the nonfluorescent and the combined values, but not for the fluorescent value.

No significant effects on the percentage of pregnant recipients and the percentage of transferred embryos surviving to term were observed (Table 4). There were differences, however, in the percentage of embryos surviving to term in the pregnant recipients $(P<0.05)$, being higher for the fluorescent and the nonfluorescent embryos treated with antiserum obtained from Mouse 10. These results could have been due to embryo transfer procedures for one replicate that were more successful than for all other occasions and all other treatments (data not shown).

\section{Discussion}

It appears from results of the sperm cytotoxicity test that in this study injection of $100 \times 10^{6}$ male spleen cells three times a week for 3 weeks did not stimulate production of high titres of $\mathrm{H}-\mathrm{Y}$ 
antisera as had been previously described (White et al., 1982). The absence of significant titres in Mice $2-10$ could have been due to the induction of high zone tolerance. Billingham, Silvers \& Wilson (1965) reported induction of tolerance in half of C57 female mice injected with $550 \times 10^{6}$ male spleen cells over a 3-week period. It seems possible, therefore, that Mice 2-10 received an excessive dose of male spleen cells.

The absence of significant levels of $\mathrm{H}-\mathrm{Y}$ antibodies in Mice 3,6 and 10 was confirmed in the indirect immunofluorescent assay for detection of embryonic $\mathrm{H}-\mathrm{Y}$ antigen. Although these sera could be used to separate the embryos into a fluorescent and a nonfluorescent population, they did not correctly identify the sex of the embryos. The misclassification of embryos, especially with the low quality antisera from Mice 3, 6 and 10, could have been due to slightly damaged embryos and/or embryos with some cellular debris present, which tended to show localized areas of fluorescence. The results obtained with the high titre antisera from Mice $1 \mathrm{~N}, 1 \mathrm{~K}$ and $2 \mathrm{~K}$ were comparable to those reported by other researchers. White et al. (1983), using monoclonal antibodies in an indirect immunoflourescent assay for detection of $\mathrm{H}-\mathrm{Y}$ antigen, separated mouse embryos into an $\mathrm{H}-\mathrm{Y}$ positive and an $\mathrm{H}-\mathrm{Y}$ negative population. Of 305 treated embryos $55 \%$ were classified as $\mathrm{H}-\mathrm{Y}$ positive and $45 \%$ as $\mathrm{H}-\mathrm{Y}$ negative. These data, plus the data obtained from Mice $1 \mathrm{~N}, 1 \mathrm{~K}$, and $2 \mathrm{~K}$, showed that the proportion of embryos classified as $\mathrm{H}-\mathrm{Y}$ positive tended to be larger than the proportion of embryos classified as H-Y negative. The percentage of young born of the predicted sex was lower in the H-Y positive group than in the H-Y negative group of embryos treated with antisera from Mice $1 \mathrm{~N}, 1 \mathrm{~K}$ and $2 \mathrm{~K}$. These observations agree with those reported by White et al. (1983) and support the observation that embryos that are slightly damaged and/or contain cellular debris can be misclassified as $\mathrm{H}-\mathrm{Y}$ positive. Although the reasons for misclassifying nonfluorescent embryos remains unclear, it was generally noted that with all the antisera tested expanded blastocysts expressed little or no fluorescence. On occasions when a sufficient number of expanded blastocysts were treated, they were transferred separately from embryos at other stages of development. Of 47 expanded blastocyst treated with H-Y antisera from Mice $1 \mathrm{~K}$ or $2 \mathrm{~K}, 39$ were classified as $\mathrm{H}-\mathrm{Y}$ negative and, when transferred to pseudopregnant recipients, produced 4 male and 5 female young (data not shown). Similar observations on the lack of or reduced expression of $\mathrm{H}-\mathrm{Y}$ antigen on mouse and cow expanded blastocysts have been made by K. L. White (personal communication). It remains to be determined whether the reduced overall fluorescence of embryos at the expanded blastocyst stage is a result of technical difficulty or a result of reduced expression and/or masking of the antigen.

The results of these experiments confirm previous reports that detection of embryonic $\mathrm{H}-\mathrm{Y}$ antigen is useful for identification of the phenotypic sex (Epstein, Smith \& Travis, 1980; White et $a l ., 1982,1983,1984)$. With the technique used there is a higher degree of inaccurate classification of fluorescent embryos as male than of nonfluorescent embryos as female. This problem may be correctable with the use of a high affinity anti-H-Y monoclonal antibody. It was also demonstrated that the sperm cytotoxicity test, which is based on changes in ATP content as a measurement of cytotoxicity, can be used to select antisera for the study of embryonic $\mathrm{H}-\mathrm{Y}$ antigen expression.

We thank S. E. Donahue for skilled technical assistance and Martha Garcia for assistance with preparation of the manuscript. Antisera from Mice $1 \mathrm{~K}$ and $2 \mathrm{~K}$ were produced in this laboratory by K. L. White.

\section{References}

Billingham, R.E., Silvers, W.K. \& Wilson, D.B. (1965) A second study on the HY transplantation antigen in mice. Proc. R. Soc. Lond. B 163, 61-89.

Bradford, G.E. (1968) Selection for litter size in mice in the presence and absence of gonadotropin treatment. Genetics, Princeton 58, 283-295.
Choi, S.C. (1978) Introductory Applied Statistics in Science. Prentice-Hall, Inc., Englewood Cliffs.

Dulbecco, R. \& Vogt, M. (1954) Plaque formation and isolation of pure lines with poliomyelitis viruses. $J$. exp. Med. 99, 167-182. 
Eichwald E.J. \& Silmser, C.R. (1955) Communication. Transplant. Bull. 2, 148-149.

Eklund, J. \& Bradford, G.E. (1976) A note on short term selection of birth weight in mice. Anim. Prod. 22, 127-130.

Epstein, C.J., Smith, S. \& Travis, B. (1980) Expression of H-Y antigen on preimplantation mouse embryos. Tissue Antigens 15, 63-67.

Goldberg, E.H., Boyce, E.A., Bennett, D., Scheid, M. \& Carswell, E.A. (1971) Serological demonstration of $\mathrm{H}-\mathrm{Y}$ antigen on mouse sperm. Nature, Lond. 232, 478-480.

Koo, G.C. \& Varano, A. (1981) Inhibition of H-Y cellmediated cytolysis by monoclonal $\mathrm{H}$-Y-specific antibody. Immunogenetics 14, 183-188.

Koo, G.C., Reidy, J.A. \& Nagamine, C.M. (1983) H-Y antigen in XO mice. Immunogenetics 18, 37-44.

Krco, C.J. \& Goldberg, E.H. (1976) H-Y (male) antigen detection on eight-cell mouse embryos. Science, $N . Y$. 193, 1134-1135.

Little, J.M. \& Hills, F.J. (1978) Agricultural Experimentation. Design and Analysis. John Wiley and Sons, New York.

Simpson, E., McLaren, A. \& Chandler, P. (1982) Evidence for two male antigens in mice. Immunogenetics 15, 609-614.

Tung, P.S., Gore-Langton, R.E. \& Fritz, I.B. (1982) An objective sperm cytotoxicity assay for male-specific antisera based on ATP levels of unlysed cells. Application to assay of $\mathrm{H}-\mathrm{Y}$ antigen. $J$. Reprod. Immun. 4, 315-324.

Wachtel, S.S. (1984) H-Y antigen in the study of sex determination and control of sex ratios. Theriogeno$\log y$ 21, 18-28.

Wachtel, S.S., Koo, G.C. \& Boyce, E.A. (1975) Evolutionary conservation of $\mathrm{H}-\mathrm{Y}$ (male) antigen. Nature, Lond. 254, 270-272.

Wachtel, G.M., Wachtel, S.S., Nakamura, D., MoreiraFilho, G.A., Brunner, M. \& Koo, G.C. (1984) H-Y antibodies recognize the $\mathrm{H} \cdot \mathrm{Y}$ transplantation antigen. Transplantation 37, 8-14.

White, K.L., Lindner, G.M., Anderson, G.B. \& BonDurant, R.H. (1982) Survival after transfer of "sexed" mouse embryos exposed to $\mathrm{H}-\mathrm{Y}$ antigen. Theriogeno$\log y 18,655-662$.

White, K.L., Lindner, G.M., Anderson, G.B. \& BonDurant, R.H. (1983) Cytolytic and fluorescent detection of $\mathrm{H}-\mathrm{Y}$ antigens on preimplantation mouse embryos. Theriogenology 19, 701-705.

White, K.L., Bradbury, M.W., Anderson, G.B. \& BonDurant, R.H. (1984) Immunofluorescent detection of a male-specific factor on preimplantation bovine embryos. Theriogenology 21, 275, Abstr.

Received 31 October 1984 